\author{
O四宮孝史（株式会社エヌエスデー） \\ 佐藤陽彦 (九州芸術工科大学) \\ Comparisons of accommodation under monocular and binocular vision \\ in depth perception. \\ Takashi SHINOYIYA (NISHINIPPON SYSTEY DEVELOPIENT CO. , LTD. ) \\ Haruhiko SATO(KYUSHU INSTITUTE OF DESIGN)
}

\section{1. はじぬに}

ヒトの視覚による奥行量の弁別は、両眼視 の場合、輻䡚・調節・両眼視差・網膜像の大 きさ等によりなされる。単眼視に於いては、 網膜像の大きさ以外は焦点調節により知覚さ れると考えられる。

調節は、網膜上に焦点を合わせるための水 晶体を支える毛様体小帯と毛様体筋の緊張と 弛緩作用である筋感覚情報を源とする情報処 理である。また、眼の焦点調節機構は眼球運 動や瞳孔調節機構とともに網膜.上に像を結像 させ、その像を保持安定させるという機能を 互いに補完しあいながら果たしている。

両眼視に於いても、精密な焦点調節の場合 には網膜像の状態からも情報を得ている。

調節は、ボケに関する情報を主として、そ の他の手掛かりは補助的な手段として利用さ れていると解される。

即ち焦点調節機構では、ボケに関する情報 が最も本質的な役割を果たしていると考えら れる。

\section{2. 研究目的}

ヒトの眼の焦点深度の特性を活用した観察 方法、即ち奥行弁別闌值を高める方法によっ て焦点調節（奥行弁別）作業を行った場合の、 単眼視と両眼視との弁別闌値の比較を行うこ と、並びに利き眼と利き眼でない眼の弁別闌 值の比較を行うことで、奥行知覚に於ける視 調節機能を利き眼とからめて実験を通して考 察した。

\section{3. 研究方法}

左右眼の独立した光学系を有する双眼式実

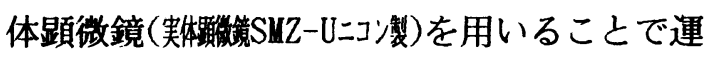
動視差要因の排除、観察距離の固定、両眼輻 輳角ならびに両眼回旋点間距離の矯正、接眼 光学系による視度補正などを機器により行い、 視認性要因の個人差を排除することで変動要 因を限定して実験を行った。視標は表面に微 細な質感を持った球形粒子を使用した。

その他の実験条件は、顕微鏡総合拡大倍率 15 倍, 観察距離 $250 \mathrm{~m} / \mathrm{m}$, 両眼輻軑角 $12.6^{\circ}$, 両

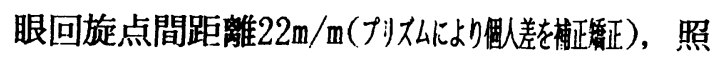
明方法は落射照明装置により輝度を均一に保っ た。また陰影効果が生じないよう工夫した。 被験者は眼科的疾患のないこ之並びに利き眼 をあらかじめ確認済みの 22 30歳の男子14名 （右眼利き、左眼利き各 7 名）を起用した。

尚、観察方法については視標の球形粒子へ の焦点合わせの方法を遠点側から焦点を合わ せるように、そして奥行量の比較は頂点とそ の周辺部で行うように被験者に事前に指示・ 訓練をしたうえで実験を行った。

\section{4. 結果及び考察}

（1）右眼利きの被験者の場合（図-1)

弁別閥値近傍までの奥行弁別機能は、両眼 視が単眼視に比べて有利であった。

即ち、奥行感が充分に知覚できる領域では、 両眼視、利き目の単眼視、利き目でない眼の 単眼視ともにその機能に差異はないが、弁別 闌値近傍における実験結果からは、奥行弁別 
の主機能としては両眼視が果たしている可能 性を示唆する結果であった。

また、弁別闌近傍での利き眼の影響につい ては、利き眼 (右眼) が有利な結果となった。

次に奥行弁別閾値を過ぎて、錯視領域に於 ける弁別機能は、両眼視と利き眼 (右眼) の 単眼視との差異はなかった。

そして、弁別能力の高い順位は、(1)両眼視、

(2)利き眼（右眼）の単眼視、(3)利き眼でない

図-1 利き眼が右眼の埸合 $(N=7)$

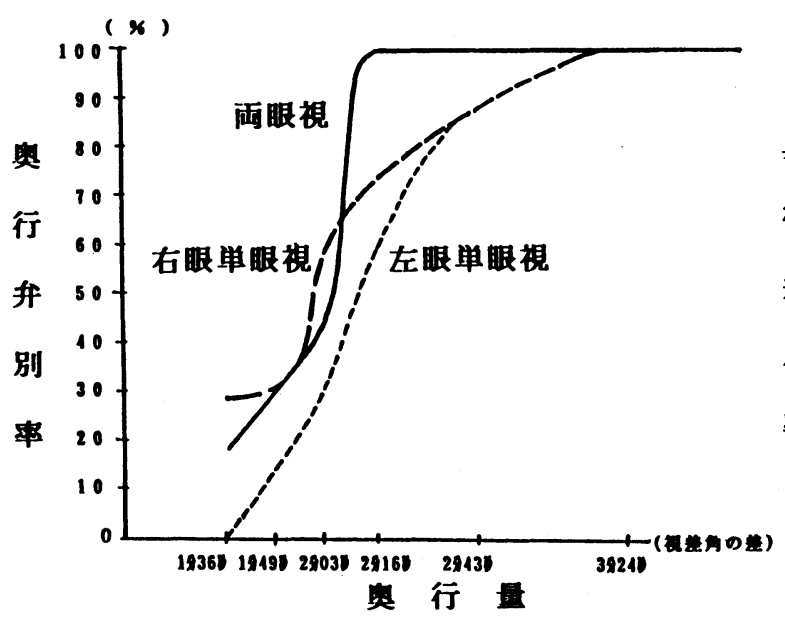

眼 (左眼) の単眼視となった。即ち、右眼利 きの場合には、利き眼 (右眼) 優位の左右差 が認められた。

（2）左眼利きの被験者の場合（図-2）

奥行弁別闌值近傍までの奥行弁別機能は、 右眼利きの場合と同様に両眼視が単眼視に比 べて有利であった。

また、弁別䦨値近傍における実験結果から、 奥行弁別の主機能しして両眼視が果たしてい る可能性を示唆する結果となった。

そして、弁別闌值近傍での利き眼の影響に ついては、利き眼でない眼 (右眼) が若干有 利な結果となった。

次に奥行弁別䦨值を過ぎた錯視領域に於け る弁別機能の比較では、3方法による弁別率 の差異は見受けられなかった。

この時、弁別能力の高い順位は、(1)両眼視、

(2)利き眼でない眼 (右眼) の単眼視、(3)利き
眼 (左眼) の単眼視であった。

即ち、単眼視における左右差は、さほよ゙顕 著ではないが利き眼（右眼）とは逆に、利き 眼ではない右眼が有利な結果となった。

5.まとめ

（1）奥行量が充分に存在する領域では、両 眼視、単眼視の利き眼、単眼視の利き眼でな い眼、それぞれ差異なく奥行が弁別されてい る事が確認された。

因一２利き眼が左眼の場合 $(\mathrm{N}=7)$

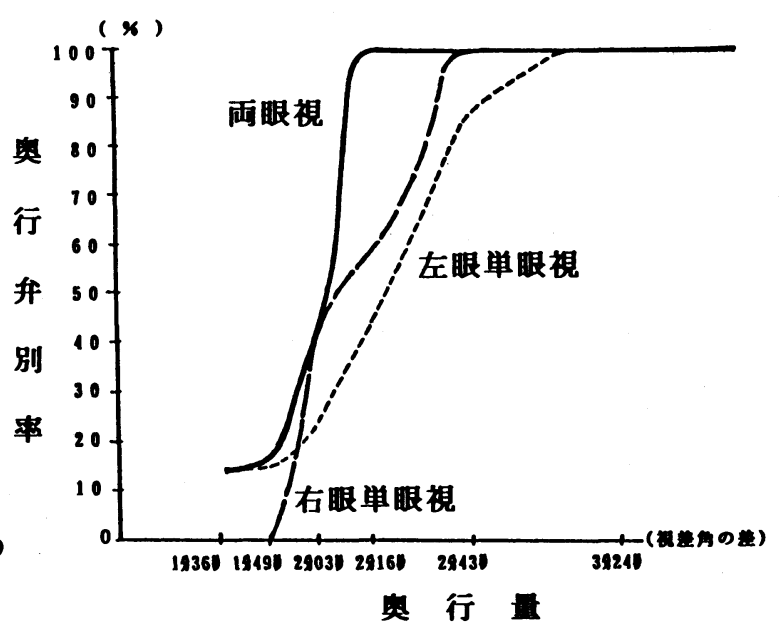

（2）奥行弁別闌値近傍に於ける弁別では、 両眼視が優位に機能しているここが確認され た。

（3）弁別閾値近傍から錯視領域に於ける単 眼視の左右差の比較では、右眼利きと左眼利 きの被験者共に、右眼の方が弁別が有利なこ とが明らかとなった。

（4）両眼視は充分な奥行量がある場合には 有利に働くが、弁別闌值以下の奥行量の領域 では、単眼 (右眼) が㭪完機能を担っている 可能性が推察された。

\section{6. 参考文献}

（1）田䗁京二編 : 視覚情報処理, 7 11, 1979 .

(2)B. Rogers and M. Graham:Montion para1lax as an independent cue for depth perception, 8, 125 134, 1979.

（3）応用物理学会光学䁅話会編: 生理光学, 朝倉書店, 115 -117, 1943. 